\title{
Investigation of Motivation Levels of Individuals Doing Fitness and Kickbox for Recreative Activity Purpose in Terms of Some Variables
}

\author{
Erdi Kaya \\ Correspondence: Erdi Kaya, Mediterranean University Faculty of Sports Sciences, Turkey. \\ Received: June 17, $2019 \quad$ Accepted: July 14, $2019 \quad$ Online Published: July 22, 2019 \\ doi:10.11114/jets.v7i10.4325 URL: https://doi.org/10.11114/jets.v7i10.4325
}

\begin{abstract}
The aim of this study is to determine the correlation of motivation levels of those who do fitness and kickbox exercises for recreative activity in Antalya Province in terms of some variables. The sampling group of the research is consisted of individuals who do fitness and kickbox for the recreative purpose in Antalya province. "Recreational Exercise Motivation Measure" (REMM) developed for the purpose of determining the factors which can motivate the individuals to the exercise was used as a data collection tool in the study. Totally 190 individuals participated into the study. SPSS 22.0 program was used for the analysis of data obtained. While Independent $\mathrm{T}$ test was used in comparison of the motivation factors by the participants' gender, exercise type they perform and status of supplement, OneWay ANOVA analysis was used in comparison of the motivation factors by the age groups, income status, educational background and starting time of the exercise.
\end{abstract}

Keywords: recreation, fitness, Kickbox, motivation

\section{Introduction}

Leisure time requirement that has been present in any period of the history has been evaluated from different point of views in every phase. For instance, it was evaluated as a necessary, compulsory and limited time for the purpose of maintaining and increasing the productivity of people in business life, a time serving to such desires as relaxation, recreation, enjoying the life and a process serving to individual and social representation such as mental relief, providing self-confidence or nature revival. Researchers such as Rojek, Robets, Kraus, Kelly, Parker, and Pronovost who reported their opinions on concepts related with leisure time referred that the concept has experienced a meaning and content confusion together with the modern period or liberalism in terms of the management discipline after the industrial revolution. However, there were times when the leisure time phenomenon included into the life with different meanings apart from its basic meanings came under the rule of local administration and government (Aytaç, 2005: 1-22).

First of which is Self-Determination Theory (SDT) whose foundations were built and conceptualized by Deci and Ryan (Deci 1975, Deci and Ryan 1985: 237-238), the second is Achievement Goal Theory (AGT) (Ames 1992: 261-271, Dweck 1986: 1040-1048, Nichollas 1989: Robert 1993: 405-420) and the last is the Requirement Theory (RT) (Ibrahim and Cordes, 2002). Why the individuals participate into the recreative sportive activities has been a subject which attracts the attention of scientists for long time. Numerous studies were conducted for learning and detecting the factors motivating individuals to such activities in the sports, exercise and recreation fields. According to STD, there are three conditions motivating the individuals. These are amotivation, intrinsic motivation and extrinsic motivation. For this reason, the factors motivating the individuals were also discussed from two point of views. Of these motivating factors; intrinsic motivation is the motivation provided by intrinsic factors and extrinsic motivation is the motivation provided by extrinsic factors. These theories dealt with how often intrinsic and extrinsic factors are perceived as stimulant since the status of participation into recreational sports/exercise resulted from stimulants lead to the motivational differentiation (Fuzhong, 1999: 97-115). The aim of the activity is the leading one among the factors motivating the individuals to exercise/sports, as well as the other benefits acquired by intrinsic and extrinsic motivation obtained from the individuals. Once the definition of motivation concept is examined, it is consisted of intrinsic and extrinsic stimulants and the individual reaches a certain motivation level through stimulants or motives (Carroll inave Alexandris, 1997: 281).

According to a theory developed by Cannon (1939), instabilities resulted from intrinsic or extrinsic factors take the organism away from the state of balance. Organism takes action for returning to the state of balance. Motive/motivation 
enables this organism to take action. Motivation or stimulating is defined as "ideas, hopes, shortly desire, requirement and fears motivating the individual, determining the directions of his/her actions" (Fındıkçı, 2000: 373). In this regard, it is seen that the motivating factors have an important place in participation of individuals into the recreational exercises. The participation of individuals who do exercise into recreational activities is of importance in terms of searching the motivation factors; consuming the leisure time of individuals more qualified, transferring the conscious of productive leisure time, doing more recreational activity in their leisure times and most importantly, being imprinted the understanding of "lifelong sports for everybody" in their mind (Erdoğan and Bahadır, 2019: 58). The participation of individuals into activities for spending more qualified time may be provided with practices which increase their motivations and raise their sports conscious.

\section{Material and Method}

"Recreational Exercise Motivation Measure" (REMM) developed for the purpose of determining the factors which can motivate the individuals to the exercise was used as a data collection tool in the study. Totally 190 individuals participated into the study. SPSS 22.0 program was used for the analysis of data obtained. While Independent $\mathrm{T}$ test was used in comparison of the motivation factors by the participants' gender, exercise type they perform and status of supplement, OneWay ANOVA analysis was used in comparison of the motivation factors by the age groups, income status, educational background and starting time of the exercise. The sampling group of the research is consisted of individuals who do fitness and kickbox for the recreative purpose in Antalya province.

\section{Findings}

SPSS 22.0 program was used for the analysis of data obtained. While Independent $T$ test was used in comparison of the motivation factors by the participants' gender, exercise type they perform and status of supplement, OneWay ANOVA analysis was used in comparison of the motivation factors by the age groups, income status, educational background and starting time of the exercise.

Table 1. Frequency and Percentage Distributions of Demographic Information of Participants

\begin{tabular}{|c|c|c|c|}
\hline Variable & Sub-variable & f & $\%$ \\
\hline \multirow{2}{*}{ Gender } & Male & 89 & 47,1 \\
\hline & Female & 100 & 52,9 \\
\hline \multirow{5}{*}{ Age group } & 16-20 years old & 20 & 10,6 \\
\hline & $21-25$ years old & 68 & 36,0 \\
\hline & $26-30$ years old & 65 & 34,4 \\
\hline & $31-35$ years old & 15 & 7,9 \\
\hline & $35+$ years old & 21 & 11,1 \\
\hline \multirow{4}{*}{ Income state } & No income & 39 & 20,6 \\
\hline & 500 - 1999 TRY & 35 & 18,5 \\
\hline & 2000 - 3499 TRY & 69 & 36,5 \\
\hline & $3499+$ TRY & 46 & 24,3 \\
\hline \multirow{4}{*}{ Educational Background } & High School & 41 & 21,7 \\
\hline & Associate degree & 28 & 14,8 \\
\hline & Bachelor's degree & 99 & 52,4 \\
\hline & Master's degree & 21 & 11,1 \\
\hline \multirow{2}{*}{ Type of exercise } & Fitness & 126 & 66,7 \\
\hline & Kickbox & 63 & 33,3 \\
\hline \multirow{6}{*}{ Starting time of exercise } & Less than 1 month & 20 & 10,6 \\
\hline & 1-6 months & 51 & 27,0 \\
\hline & 6-12 months & 33 & 17,5 \\
\hline & $12-18$ months & 18 & 9,5 \\
\hline & 18-24 months & 17 & 9,0 \\
\hline & $24+$ months & 50 & 26,5 \\
\hline \multirow{2}{*}{ State of using Supplement } & Yes & 49 & 25,9 \\
\hline & No & 140 & 74,1 \\
\hline
\end{tabular}

$47,1 \%$ of the participants is male, $52,9 \%$ is female, $10,6 \%$ is in the age group of $16-20,36 \%$ in the age group of $21-25$, $34,4 \%$ in the age group of $26-30,7,9 \%$ in the age group of $31-35$ and $11,1 \%$ in the age group $35+$. While $20,6 \%$ of the participants does not have an income, $18,5 \%$ has an income amounting to $200-1999$ TRY, 36,5\% has an income amounting to $2000-3499$ TRY, $24,3 \%$ has $3499+$ TRY income. $21,7 \%$ of the participants of the research is high school graduate, $14,8 \%$ is associate degree graduate, $52,4 \%$ is bachelor's degree graduate, $11,1 \%$ is the graduate of master's degree. $66,7 \%$ of the participants is doing fitness, $33,3 \%$ is doing kickbox exercise. While $10,6 \%$ of the participants has been doing exercise for less than 1 month, $27 \%$ for 1-6 months, $17,5 \%$ for $6-12$ months, $9,5 \%$ for $12-18$ months, $9 \%$ for $8-24$ months, $26,5 \%$ for $24+$ months and $25,9 \%$ of the participants is using supplement. 
Table 2. Descriptive Statistics of Recreative Exercise Motivation Factors of Participants

\begin{tabular}{c|c|c|c}
\hline Factor & $\mathbf{N}$ & $\mathbf{X}$ & Sd \\
\hline Health & 189 & 75,08 & 11,331 \\
\hline Competition & 189 & 49,88 & 10,689 \\
\hline Body and appearance & 189 & 32,56 & 5,277 \\
\hline Social and recreation & 189 & 63,35 & 13,957 \\
\hline Skill development & 189 & 32,93 & 5,731 \\
\hline
\end{tabular}

The lowest and the highest scores to be obtained from the health factor is 18-90, the lowest and highest scores to be obtained from competition factor is 14-70, the lowest and highest scores to be obtained from body and appearance factor is 8-40, the lowest and highest scores to be obtained from social and recreation factor is $18-90$, the lowest and highest scores to be obtained from skill development factor is 8-40. In this regard, when table is examined, it is seen that motivations of participants in health, competition, body and appearance and skill development factors are high, they have near-high motivation above the intermediate level in the social and recreation factor.

Table 3. Comparison of Recreative Exercise Motivation Factors of Participants by Income States

\begin{tabular}{|c|c|c|c|c|c|c|}
\hline Factor & Income State & $\mathbf{N}$ & $\mathbf{X}$ & Sd & $\mathbf{F}$ & $\mathbf{P}$ \\
\hline \multirow{4}{*}{ Health } & None & 39 & 73,92 & 11,172 & \multirow{4}{*}{3,321} & \multirow{4}{*}{, 021} \\
\hline & 500 - 1999 TRY & 35 & 75,54 & 12,860 & & \\
\hline & $2000-3499$ TRY & 69 & 72,74 & 12,390 & & \\
\hline & $3499+$ TRY & 46 & 79,24 & 6,832 & & \\
\hline \multirow{4}{*}{ Competition } & None & 39 & 50,33 & 10,693 & \multirow{4}{*}{, 454} & \multirow{4}{*}{, 715} \\
\hline & $500-1999$ TRY & 35 & 50,40 & 11,057 & & \\
\hline & $2000-3499$ TRY & 69 & 48,71 & 10,761 & & \\
\hline & $3499+$ TRY & 46 & 50,87 & 10,487 & & \\
\hline \multirow{4}{*}{$\begin{array}{c}\text { Body and } \\
\text { appearance }\end{array}$} & None & 39 & 31,36 & 5,470 & \multirow{4}{*}{4,131} & \multirow{4}{*}{, 007} \\
\hline & $500-1999$ TRY & 35 & 33,57 & 5,321 & & \\
\hline & $2000-3499$ TRY & 69 & 31,49 & 5,596 & & \\
\hline & $3499+$ TRY & 46 & 34,41 & 3,879 & & \\
\hline \multirow{4}{*}{$\begin{array}{l}\text { Social and } \\
\text { recreation }\end{array}$} & None & 39 & 63,23 & 13,055 & \multirow{4}{*}{,943 } & \multirow{4}{*}{,421 } \\
\hline & $500-1999$ TRY & 35 & 66,40 & 14,230 & & \\
\hline & $2000-3499$ TRY & 69 & 61,58 & 14,545 & & \\
\hline & $3499+$ TRY & 46 & 63,80 & 13,600 & & \\
\hline \multirow{4}{*}{ Skill development } & None & 39 & 33,03 & 4,528 & \multirow{4}{*}{1,646} & \multirow{4}{*}{, 180} \\
\hline & 500 - 1999 TRY & 35 & 33,94 & 6,264 & & \\
\hline & $2000-3499$ TRY & 69 & 31,78 & 5,931 & & \\
\hline & 3499+ TRY & 46 & 33,78 & 5,792 & & \\
\hline
\end{tabular}

When Table is examined, it is seen that the competition, social and recreation, skill development motivation factors of the factors directing the participants to the recreative exercise do not differ at a statistically significant level by the income state $(p>0,05)$, health and body and appearance motivation factors differ at a statistically significant level by the income state $(\mathrm{p}<0,05)$. It is seen in the health motivation factor in which there is a significant difference that the body and appearance motivation level of the participants who have a monthly income amounting to 3499+ TRY is significantly higher than the participants whose monthly income is $2000-3499$ TRY ( $<<0,05)$. It is seen in the body and appearance motivation factor in which there is a significant difference that the body and appearance motivation level of the participants who have a monthly income amounting to 3499+ TRY is significantly higher than the participants who have no monthly income and whose monthly income is $2000-3499$ TRY $(p<0,05)$. 
Table 4. Comparison of Recreative Exercise Motivation Factors of Participants by the Type of the Exercise They Perform

\begin{tabular}{|c|c|c|c|c|c|c|}
\hline Factor & $\begin{array}{c}\text { Type of } \\
\text { Exercise }\end{array}$ & $\mathbf{N}$ & $\mathbf{X}$ & Sd & $\mathbf{t}$ & $\mathbf{P}$ \\
\hline \multirow{2}{*}{ Health } & Fitness & 126 & 73,54 & 12,573 & \multirow{2}{*}{$-2,695$} & \multirow{2}{*}{,008 } \\
\hline & Kickbox & 63 & 78,17 & 7,487 & & \\
\hline \multirow{2}{*}{ Competition } & Fitness & 126 & 47,94 & 10,627 & \multirow{2}{*}{$-3,656$} & \multirow{2}{*}{, 000} \\
\hline & Kickbox & 63 & 53,78 & 9,782 & & \\
\hline \multirow{2}{*}{$\begin{array}{l}\text { Body and } \\
\text { appearance }\end{array}$} & Fitness & 126 & 31,93 & 5,569 & \multirow{2}{*}{$-2,358$} & \multirow{2}{*}{,019 } \\
\hline & Kickbox & 63 & 33,83 & 4,412 & & \\
\hline \multirow{2}{*}{$\begin{array}{l}\text { Social and } \\
\text { recreation }\end{array}$} & Fitness & 126 & 61,16 & 14,243 & \multirow{2}{*}{$-3,129$} & \multirow{2}{*}{,002 } \\
\hline & Kickbox & 63 & 67,75 & 12,341 & & \\
\hline \multirow{2}{*}{ Skill development } & Fitness & 126 & 32,17 & 6,051 & \multirow{2}{*}{$-2,587$} & \multirow{2}{*}{, 010} \\
\hline & Kickbox & 63 & 34,43 & 4,727 & & \\
\hline
\end{tabular}

When Table is examined, it is seen that health, competition, body and appearance, social and recreation, skill development motivation factors of the factors directing the participants to recreative exercise differ at a statistically significant level by the type of the exercise and the motivation level of participants who do kickbox in all factors is significantly higher than the participants who do fitness $(p>0,05)$.

Table 5. Comparison of Recreative Exercise Motivation Factors of Participants by the Starting time of the Exercise

\begin{tabular}{|c|c|c|c|c|c|c|}
\hline Factor & Time & $\mathbf{N}$ & $\mathbf{X}$ & Sd & $\mathbf{F}$ & $\mathbf{P}$ \\
\hline \multirow{6}{*}{ Health } & Less than 1 month & 20 & 73,05 & 7,536 & \multirow{6}{*}{2,091} & \multirow{6}{*}{, 068} \\
\hline & $1-6$ months & 51 & 71,37 & 14,451 & & \\
\hline & 6-12 months & 33 & 76,21 & 9,367 & & \\
\hline & 12-18 months & 18 & 76,67 & 7,554 & & \\
\hline & 18-24 months & 17 & 76,41 & 6,325 & & \\
\hline & $24+$ months & 50 & 77,92 & 11,863 & & \\
\hline \multirow{6}{*}{ Competition } & Less than 1 month & 20 & 47,85 & 6,499 & \multirow{6}{*}{2,384} & \multirow{6}{*}{, 040} \\
\hline & $1-6$ months & 51 & 47,14 & 10,558 & & \\
\hline & 6-12 months & 33 & 48,06 & 10,461 & & \\
\hline & 12-18 months & 18 & 51,22 & 11,306 & & \\
\hline & 18-24 months & 17 & 52,76 & 6,619 & & \\
\hline & $24+$ months & 50 & 53,24 & 12,302 & & \\
\hline \multirow{6}{*}{$\begin{array}{c}\text { Body and } \\
\text { appearance }\end{array}$} & Less than 1 month & 20 & 31,80 & 4,086 & \multirow{6}{*}{2,138} & \multirow{6}{*}{, 063} \\
\hline & $1-6$ months & 51 & 31,04 & 5,814 & & \\
\hline & 6-12 months & 33 & 32,09 & 4,876 & & \\
\hline & 12-18 months & 18 & 33,06 & 4,151 & & \\
\hline & 18-24 months & 17 & 34,00 & 3,410 & & \\
\hline & $24+$ months & 50 & 34,06 & 5,888 & & \\
\hline \multirow{6}{*}{$\begin{array}{l}\text { Social and } \\
\text { recreation }\end{array}$} & Less than 1 month & 20 & 61,95 & 9,594 & \multirow{6}{*}{2,166} & \multirow{6}{*}{, 060} \\
\hline & $1-6$ months & 51 & 59,25 & 14,619 & & \\
\hline & 6-12 months & 33 & 61,61 & 14,217 & & \\
\hline & 12-18 months & 18 & 67,83 & 14,030 & & \\
\hline & 18-24 months & 17 & 66,88 & 9,286 & & \\
\hline & $24+$ months & 50 & 66,44 & 14,948 & & \\
\hline \multirow{6}{*}{$\begin{array}{c}\text { Skill } \\
\text { development }\end{array}$} & Less than 1 month & 20 & 29,95 & 4,249 & \multirow{6}{*}{2,306} & \multirow{6}{*}{,046 } \\
\hline & 1-6 months & 51 & 31,88 & 6,507 & & \\
\hline & 6-12 months & 33 & 33,52 & 5,316 & & \\
\hline & 12-18 months & 18 & 33,11 & 4,497 & & \\
\hline & 18-24 months & 17 & 34,12 & 4,428 & & \\
\hline & $24+$ months & 50 & 34,32 & 6,039 & & \\
\hline
\end{tabular}

When Table is examined, it is seen that health, body and appearance, social and recreation motivation factors of the factors directing the participants to recreative exercise do not differ at a statistically significant level by the starting time 
of the exercise ( $p>0,05)$, but, the competition and skill development motivation factors differ at a statistically significant level by the starting time of the exercise $(p<0,05)$. It is seen in the competition motivation factor in which there is significant difference that the competition motivation level of the participants doing exercise for $24+$ months is significantly higher than the participants doing exercise for 1-6 months $(\mathrm{p}<0,05)$. It is seen in the skill development factor with significant difference that the competition motivation level of the participants doing exercise for 24+ months is significantly higher than the participants doing exercise for less than 1 month $(\mathrm{p}<0,05)$.

Table 6. Comparison of Recreative Exercise Motivation Factors of Participants by the State of Using Supplement

\begin{tabular}{c|c|c|c|c|c|c}
\hline Factor & State of use & $\mathbf{N}$ & $\mathbf{X}$ & $\mathbf{S d}$ & $\mathbf{t}$ & $\mathbf{p}$ \\
\hline \multirow{2}{*}{ Health } & Yes & 49 & 75,76 & 13,317 & \multirow{2}{*}{, 480} & \multirow{2}{*}{, 632} \\
\cline { 2 - 5 } Competition & No & 140 & 74,85 & 10,592 & \\
\cline { 2 - 5 } & Yes & 49 & 52,73 & 10,818 & \multirow{2}{*}{2,191} & \multirow{2}{*}{, 030} \\
\cline { 2 - 5 } $\begin{array}{c}\text { Body and } \\
\text { appearance }\end{array}$ & No & 140 & 48,89 & 10,500 & \multirow{2}{*}{2,047} & \multirow{2}{*}{, 042} \\
\cline { 2 - 5 } $\begin{array}{c}\text { Social and } \\
\text { recreation }\end{array}$ & No & 49 & 33,88 & 5,028 & \multirow{2}{*}{, 672} & \multirow{2}{*}{, 502} \\
\cline { 2 - 5 } Skill development & No & 140 & 32,10 & 5,301 & \multirow{2}{*}{, 252} \\
\cline { 2 - 5 } & Yes & 49 & 64,51 & 13,964 & 1,149 & \\
\hline
\end{tabular}

When Table is examined, it is seen that health, social and recreation, skill development motivation factors of the factors directing the participants to recreative exercise do not differ at a statistically significant level by the state of using supplement $(\mathrm{p}>0,05)$, the competition and body and appearance motivation factors differ at a statistically significant level by the state of using supplement $(\mathrm{p}<0,05)$. It is seen in the competition and body and appearance motivation factors in which there is a significant difference that the motivation level of the participants using supplement are significantly higher than the participants not using supplement $(\mathrm{p}<0,05)$.

\section{Discussion and Conclusion}

When the findings of individuals participating into our study given in Table 2 are examined, it is seen that motivations in health, competition, body and appearance and skill development factors are high, they have near-high motivation above the intermediate level in the social and recreation factor. While it is seen that the preferential factor motivating the individuals doing fitness and kickbox to the recreational exercise is the health factor, it is respectively followed by social and recreation, competition, skill development and body and appearance factors. In the study conducted by Karakaş et al., (2015) showing similarity regarding that health factor is ranked first, it was found that the first factor motivating the participants to the recreational exercise is the health and it is respectively followed by the skill development, body and appearance, social and recreation and competition factor.

When Table 3 is examined, it is seen that the competition, social and recreation, skill development motivation factors of the factors directing the participants to the recreative exercise do not differ at a statistically significant level by the income state $(\mathrm{p}>0,05)$, health and body and appearance motivation factors differ at a statistically significant level by the income state $(\mathrm{p}<0,05)$. Once score means of the health motivation factor are examined, score means of the individuals whose monthly income is $3499+$ TRY $(\bar{x}=79,24)$ are higher than the score means of the individuals whose monthly income is 2000-3499 TRY ( $\bar{x}=72,74)$. Accordingly, while it is seen that health is an important motivating factor in the recreational exercise participation states of individuals whose income level is high, it is seen that it is not quite important in the individuals whose income level is lower. Once the score means of body and appearance motive factor are examined, it is found that score means of the individuals whose monthly income is $3499+$ TRY $(\overline{\mathrm{x}}=34,41)$ are higher than those who have no monthly income $(\overline{\mathrm{x}}=31,36)$ and score means of those whose monthly income is $2000-3499$ TRY $(\overline{\mathrm{x}}=31,49)$. In such a case, while it is considered that body and appearance is an important motivational source in the recreational exercise participation for the individuals whose income level is high, it is seen that the case is not same for the individuals whose income level is low. There is a linear relationship between the income state variable and health and body and appearance factors. As the income level increases, their health and body and appearance motivations increase in the participation of individuals into the recreational exercise. Müderrisoğlu and Uzun (2004) noted that the income is one of the most effective factors in the recreational preferences, there is a relationship between participation into recreational activities and income. In another study, a significant difference was found between the income state 
variable and competition, body and appearance, social and recreation and skill development motivation factors, however, it was stated that this difference is reserve. Although it is considered that the body and appearance factor showed similarity with our study by the significance condition as a result of the findings, the reverse nature of this significance is completely contrary finding to our study (Çetinkaya, 2015: 119).

When Table 4 is examined, it is seen that health, competition, body and appearance, social and recreation, skill development motivation factors of the factors directing the participants to recreative exercise differ at a statistically significant level by the type of the exercise $(\mathrm{p}>0,05)$. Once the score means of the recreative exercise motivation factors by the type of exercise are examined, means of the individuals doing kickbox $(\bar{x}=78,17)$ are higher than the means of the individuals doing fitness $(\bar{x}=73,54)$ in the health motivation factor. In the competition motivation factor, means of the individuals doing kickbox $(\overline{\mathrm{x}}=53,78)$ are higher than the scores of the individuals doing fitness $(\overline{\mathrm{x}}=47,94)$. Means of the individuals doing kickbox $(\overline{\mathrm{x}}=33,83)$ are higher than the means of the individuals doing fitness $(31,93)$ in the body and appearance motivation factor. In the social and recreation motivation factor, means of the individuals doing kickbox $(\overline{\mathrm{x}}=67,75)$ are higher than the means of the individuals doing fitness $(\overline{\mathrm{x}}=61,16)$. In the skill development motivation factor; means of the individuals doing kickbox $(\overline{\mathrm{x}}=34,43)$ are higher than the means of the individuals doing fitness $(32,17)$. According to the finding results; while it is considered that health, competition, body and appearance, social recreation and skill factors are those increasing the motivation in the participations of the individuals doing kickbox into the recreational exercises by the type of exercise; these factors do not affect the motivation in the individuals doing fitness. A linear relationship was found between all motivation factors and the variable of exercise type. Once the literature review is made, while the competition motivation of athletes in different branches differs in a study performed over athletes competing in the university teams (Yıldırım, 2017: 48), it is found in another study that the fitness exercise type does not show a significant difference with the recreational exercise motivations of the individuals by the gender variable at the end of the investigation and it is determined that that study is contrary to our study (Ayar, 2017: 172). In the study conducted by Temel (2018), it was determined that there are significant differences at motivation levels of players of wushu and table tennis that are the different branches. According to these findings, it may be interpreted as follows; different exercise type may differentiate the motivation state.

When Table 5 is examined, it is seen that health, body and appearance, social and recreation motivation factors of the factors directing the participants to recreative exercise do not differ at a statistically significant level by the starting time of the exercise ( $>0,05)$, but, the competition and skill development motivation factors differ at a statistically significant level by the starting time of the exercise $(\mathrm{p}<0,05)$. While it is seen in the competition motivation factor in which there is significant difference that the means of the participants doing exercise for $24+$ months $(\overline{\mathrm{x}}=53,24)$ is significantly higher than the means of the participants doing exercise for 1-6 months $(\overline{\mathrm{x}}=47,14)$, it is seen in the skill development factor with significant difference that the means of the participants doing exercise for $24+$ months $(\bar{x}=34,32)$ is significantly higher than the means of the participants doing exercise for less than 1 month $(\bar{x}=29,95)(p<0,05)$. According to the study result, once the relationship between the starting time of exercise and recreational exercise participation of individuals is examined, while it is considered that the states of the individuals for being engaged in the sports for long time support their motivations in the sub-dimensions of competition and skill development, it does not affect the motivation of the individuals who do exercise for shorter time. There is a linear relationship between the state of doing sports for long time and skill development and competition motivations. As the time of doing exercise increases, the state of being motivated in the skill development and competition factor also increases. Individuals participating into long-term exercise have a more positive self-presentation and hence, they stated that they are more motivated for the exercise (Altıntaş, Aş̧̧ and Özdemir, 2007). Once the literature review is made about the study findings, while it is seen that it has similar aspects with our study in the competition and skill development factors, a positive significant relationship is found between the sub-dimensions of health, social/recreation and exercise time and this does not provide any similarity with our study (Ayar, 2017: 176). Koruç (2015) found a positive significant relationship in the health, competition, body and appearance, social/recreation and skill development dimensions at the end of the study he performed for measuring the recreational exercise between the individuals started fitness centers recently and going to the center for more than three years. While the sub-dimensions of the competition and skill development of the recreational exercise motivation measure coincide with the present study in terms of exercise participation time, it does not bear a similar feature with the sub-dimensions of body and appearance, health, social/recreation.

When Table 6 is examined, it is seen that health, social and recreation, skill development motivation factors of the factors directing the participants to recreative exercise do not differ at a statistically significant level by the state of using supplement $(p>0,05)$, the competition and body and appearance motivation factors differ at a statistically significant level by the state of using supplement $(p<0,05)$. While it is seen in the competition motivation factor in which there is a significant difference that score means of the participants using supplement $(\overline{\mathrm{x}}=52,73)$ are higher than the score means of the participant not using supplement $(\overline{\mathrm{x}}=48,89)$, it is found out in the body ad appearance factor that 
score means of participants using supplement $(\overline{\mathrm{x}}=33,88)$ are higher than the score means of the participants not using supplement $(\overline{\mathrm{x}}=32,10)$. It was concluded that while it was considered that the use of supplement in the recreational exercise participation states is a motivating factor for the individual in the body and skill development factors, it is not a motivating factor for the individuals not using supplement in the body and skill development factors .A linear relationship was found between the variable of supplement use and body and skill development factors. As the supplement use of the individuals increases, the motivation levels in the body and skill development factors also increase. In a study conducted; while $27 \%$ of the individuals participating into the study states that the use of supplement is a motivating factor in achieving the objectives in the sports, $23 \%$ states that everybody engaging in body development should use a supplement (Çavdar, 2018: 25). Çimen (2012) reported in the study performed over the elite table tennis players and coaches that $88 \%$ of the athlete states that sports drinks will provide an advantage in the long-term exercises; $76 \%$ of the athlete states that nutritional supplement is an element increasing the performance of athletes. In the study conducted by Yıldırım, Miçooğulları, Yıldırım and Şahin (2005), it was concluded that 44\% of the athletes used a nutritional supplement prior to the match.

\section{References}

Altıntaş, A., Aşçı, F. H., \& Özdemir, B. T. (2007). Benlik Sunumunun Cinsiyet ve Egzersiz Davranışı Parametrelerine Göre İncelenmesi”. Hacettepe Üniversitesi Spor Bilimleri Dergisi, 18(2), 91-99.

Ames, C. (1992). Classrooms: Goals, structures and student motivation. Journal of Education Psychology. https://doi.org/10.1037/0022-0663.84.3.261

Ayar, H. (2017) Fitness ve Crossfit Merkezlerine Rekreatif Egzersiz Amaçlı Katılımda Etkili Olan Motivasyon Faktörlerinin İncelenmesi. Uluslararası Anadolu Spor Bilimleri Dergisi, 8(3), 167-179.

Aytaç, Ö. (2005). Kapitalizm ve Boş Zaman, Osmangazi Üniversitesi Sosyal Bilimler Dergisi, 6 (1).

Cannon, W. B. (1939). The Wisdom of the Body. Revised and Enlarged Edt. New York: W.W.Norton. https://doi.org/10.1097/00000441-193907000-00031

Carroll, B., \& Alexandris, K. (1997). Engeller, Motivasyon ve Katılım Sıklığı Arasındaki İlişki Modeli. Journal of Leisure Research, 3(29), 279-299. https://doi.org/10.1080/00222216.1997.11949797

Çavdar, B., Cinel, Y., Bayazıt, B., \& Yılmaz, O. (2018). Fitness Merkezlerinde Egzersiz Yapan Bireylerin Besin Takviyesi Kullanımı ile İlgili Görüş̧erinin Belirlenmesi. Muş Alparslan Üniversitesi Uluslararası Spor Bilimleri Dergisi, 2(2): 19-28.

Çetinkaya, G. (2015). Şirket Çalışanlarını Sportif Rekreasyonel Faaliyetlere Katılmaya Motive Eden Unsurların Incelenmesi. Doktora Tezi. Marmara Üniversitesi Sağlık Bilimleri Enstitüsü, İstanbul.

Çimen O. (2012). Elit Masa Tenisçilerin ve Antrenörlerinin Beslenme Bilgisi ve Allşkanlıklarının Belirlenmesi. Doktora Tezi. Gazi Üniversitesi Sağlık Bilimleri Enstitüsü, Ankara.

Deci, E. L. (1975). Intrinsic motivation. New York: Plenum Press. https://doi.org/10.1007/978-1-4613-4446-9

Deci, E. L., \& Ryan, R. M. (1985). Intrinsic motivation and self- determination in human behavior, New York, NY: Plenum Press. https://doi.org/10.1007/978-1-4899-2271-7

Dweck, C. (1986). Motivational processes affectinin learning. American Psychologist. https://doi.org/10.1037/0003-066X.41.10.1040

Erdoğan, Ç. H., \& Bahadır, Z. (2019). Egzersiz Yapan Bireylerin Boş Zaman Etkinliklerine Katılım Motivasyonlarını Etkileyen Faktörlerin İncelenmesi. Spor ve Performans Araştırmaları Dergisi, 10(1), 56-68. https://doi.org/10.17155/omuspd.423077

Fındıkçı İ. (2000). İnsan Kaynakları Yönetimi. Alfa Yayınevi, İstanbul.

Fuzhong, L. (1999). The Exercise motivation scale: Its multifaced structure and construct validity. Journal of Applied Sport Psychology, 11(1). https://doi.org/10.1080/10413209908402953

Ibrahim, H., \& Cordes, K. A. (2002). Outdoor Reaction, Enrichment For a Lifetime. Second Edition, Sagamore Publishing, II.

Karakaş, G., Eroğlu, K. I., \& Eskiler, E. (2015). Yüzme Egzersizine Katılan Kadınların Egzersiz Motivasyonlarının İncelenmesi. III. Rekreasyon Araştırmaları Kongresi. 5-7 Kasım 2015, Eskişehir, 501-509.

Koruç, P. (2015). Does Exercising For a While Changes The Motivation of Exercise Participation. International Journal of Science Culture and Sport, 3(3), 25-31. https://doi.org/10.14486/IntJSCS430

Müderrisoğlu, H., \& Uzun, S. (2004), Abant İzzet Baysal Üniversitesi Orman Fakültesi Öğrencilerinin Rekreasyonel 
Eğilimleri, Süleyman Demirel Üniversitesi Orman Fakültesi Dergisi, Seri A(2), 108-121.

Nicholls, J. (1989). The competitive ethos and demogratic education, MA: Harvard University Press, Cambridge.

Roberts, G. (1993). Motivation in sport: Understanding and enhancing the motivation and achivement of children. In R. N. Singer, M. Murphy, ve C. K. Tennant (Eds.), Handbook of research on sport psychology. New York: Macmillan.

Temel, V. (2018). Masa Tenisi ve Wushu Sporcularının Spora Katılım Güdüleri. Gazi Beden Eğitimi ve Spor Bilimleri Dergisi, 23(3), 143-152.

Yıldırım, Y., Miçooğulları B. O., Yıldırım, İ., \& Şahin F. N. (2005). Hatay İli Amatör Basketbol Kulüplerindeki Sporcuların Beslenme Bilgi ve Alışkanlıkları. Atatürk Üniversitesi Beden Eğitimi ve Spor Bilimleri Dergisi, 7(4), $12-22$.

\section{Copyrights}

Copyright for this article is retained by the author(s), with first publication rights granted to the journal.

This is an open-access article distributed under the terms and conditions of the Creative Commons Attribution license which permits unrestricted use, distribution, and reproduction in any medium, provided the original work is properly cited. 